\title{
Expert System To Diagnose Beengal Cat Disease With Case Based Reasoning Method
}

\author{
Ananda Friska Utami ${ }^{1}$, Jonson manurung ${ }^{2}$ \\ ${ }^{1,2}$ Informatics Engineering, STMIK Pelita Nusantara, Sumatera Utara, Indonesia
}

\begin{tabular}{|c|c|}
\hline ARTICLE INFO & ABSTRACT \\
\hline Article history: & \multirow{4}{*}{$\begin{array}{l}\text { At this time, many animal lovers keep pets. Cat or cattery owners } \\
\text { sometimes find it difficult to diagnose pet cat diseases because ca } \\
\text { diseases are not the same as human diseases, which are easy to } \\
\text { diagnose and provide visible symptoms. Horas Cattery is a breeding } \\
\text { ground and provider of pet cat adoption services, including Benga } \\
\text { cats. From the observations of the authors at Horas Cattery } \\
\text { understanding of the symptoms of cat diseases is still lacking, so } \\
\text { they still rely on the expertise of experts manually, in addition, the } \\
\text { cost for treatment to a veterinarian is very expensive and there are } \\
\text { still few veterinarians. In this case, the research conducted at Horas } \\
\text { Cattery uses the Case Based Reasoning method which is one of the } \\
\text { methods of the expert system to diagnose Bengal cat disease } \\
\text { because the method is based on knowledge from previous cases } \\
\text { Based on the research conducted, it was found that the case with } \\
\text { the lowest weight was case } 13 \text {, which was } 0.2 \text {. Case } 2 \text { produces } \\
\text { high weight of } 0.6667 \text {. So the results of calculations with weights } \\
\text { show a confidence level of more than } 60 \% \text {. }\end{array}$} \\
\hline $\begin{array}{r}\text { Received Dec 01, } 2021 \\
\text { Revised Dec 15, } 2021 \\
\text { Accepted Des 26, } 2021\end{array}$ & \\
\hline \multirow{4}{*}{$\begin{array}{r}\text { Bengal Cat; } \\
\text { Case Based Reasoning } \\
\text { Method; } \\
\text { Expert System. }\end{array}$} & \\
\hline & \\
\hline & This is an open access article under the CC BY-NC license. \\
\hline & (c) (i) (\$) \\
\hline \multicolumn{2}{|l|}{ Corresponding Author: } \\
\hline \multicolumn{2}{|c|}{$\begin{array}{l}\text { Ananda Friska Utami, } \\
\text { Informatics Engineering, } \\
\text { STMIK Pelita Nusantara, Sumatera Utara, Indonesia } \\
\text { Jl. Iskandar Muda No.1 Medan, Sumatera Utara, Indonesia } \\
\text { anandafriskautami@gmail.com }\end{array}$} \\
\hline
\end{tabular}

\section{INTRODUCTION}

Bengal cat is a cat that is prone to disease. Horas Cattery is a breeding ground and provider of pet cat adoption services, including Bengal cats. From the author's observations at Horas Cattery, understanding of the symptoms of cat diseases is still lacking, so they still rely on the expertise of experts manually, in addition, the cost for treatment to the veterinarian is very expensive and the presence of veterinarians is still small (Kurniati et al., 2017). Based on the above case, an expert system is needed to develop knowledge from an expert into technology.

Expert System is a specially designed software based on Artificial Intelligence (Al), which functions to record and duplicate expert abilities (Broussard, 2015). According to S Suprapto (2018), the basic concept of an expert system contains expertise, expertise, transfer of expertise, inference, rules, and the ability to explain (Liao, 2005). An expert system (expert system) is a system that seeks to adopt human abilities or knowledge into computers to solve problems like an expert (Muktar et al., 2020). One of the methods in the expert system is Case Based Reasoning (CBR), in which case the author chooses to apply this method in diagnosing Bengal cat disease, because the CBR (Case Based Reasoning) method is an artificial intelligence approach that focuses on problem solving based on knowledge (Kamal, 2006). Based on research conducted by 
(Fidyaningsih et al., 2016) entitled "Expert System for Diagnosing Cat Diseases Using the Case Base Reasoning Method" the results obtained from the use of the Case-Based Reasoning Method can be implemented in the application of an expert system for diagnosing cat diseases with an accuracy rate of $90 \%$ and generates cat disease diagnosis output along with solutions and prevention based on 5 cat diseases (Setiawan et al., 2020), (Sutrisna et al., 2021). This study diagnoses cat diseases in general, while in this study the authors diagnose cat diseases specifically in Bengal cats. While the research conducted by (Purnomo et al., 2020) with the title "Expert System for Diagnosing Gastric Disease Using the Web-Based Case Based Reasoning Method" the results obtained are decision making from new cases based on solutions from previous cases to diagnose gastric disease, as well as provide solutions and ways of prevention based on the symptoms of the disease experienced (Salat et al., 2021), (Anggilina \& Eviyanti, 2021).

\section{METHOD}

The research framework is the stages carried out in the research.

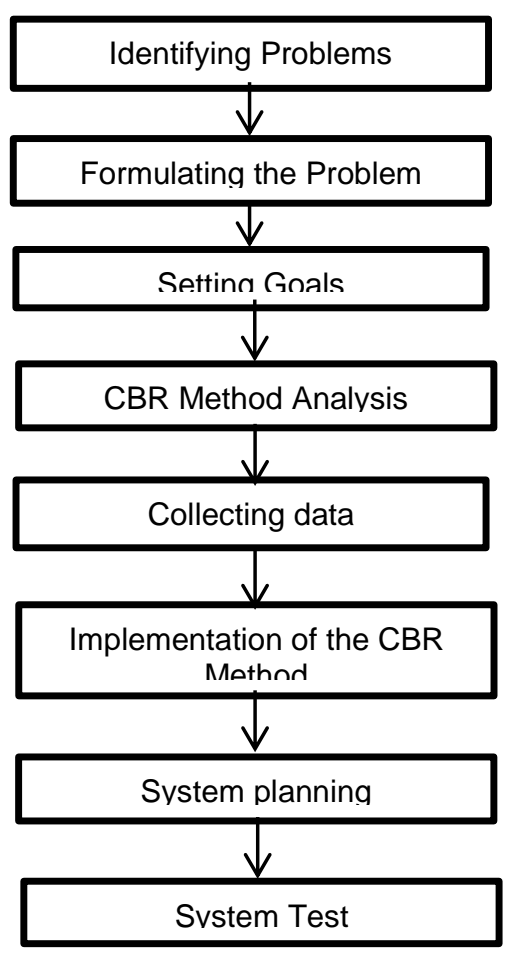

Figure 1. Research Framework

a. Identification of problems

This stage is the stage to identify the symptoms that occur in diagnosing Bengal cat disease by observing the phenomena that cause these symptoms.

b. Formulation of the problem

In this stage the author analyzes the problem by conducting a survey of previous studies that have been done regarding diagnosing cat diseases.

c. Goal Setting

This stage aims so that in this research get the final results in accordance with the goals that have been set. Before reaching the final result, the goal will be divided into subobjectives that cause the research not to arrive at the final result or even deviate, then by setting the goal will direct and measure the level of success in this research. 
d. CBR Method Analysis

In this stage the method analysis is carried out by studying and analyzing the method used, the CBR (Case Based Reasoning) method to find out how to apply it in diagnosing Bengal cat disease (De Paz et al., 2009), (Hadj-Mabrouk, 2020), (Fernandez-Riverola et al., 2006).

e. Collecting data

In this study, the authors collect data by document study, where the data obtained is not directly from the object under study, but analyzes from various sources about Bengal cat disease and previous studies.

f. CBR Method Implementation

In this stage, the implementation of the CBR method is carried out to obtain the results of the diagnosis of Bengal cat disease (Masethe et al., 2021), (Jiang et al., 2020).

g. System planning

In this stage the author designs the system using the CBR (Case Based Reasoning) method and the system will be designed using PHP

h. System Test

In this stage the system will be tested whether it is in accordance with the objectives set in the previous stage or not, also to determine the level of success of the system.

\section{RESULTS AND DISCUSSIONS}

Data analysis is an analysis of all the data needed to build an expert system to diagnose diseases in Bengal Cats. Analysis of data requirements in the manufacture of this expert system is as follows:

a. Disease data

TABLE 1.

\section{DISEASE DATA}

\begin{tabular}{cl} 
& \multicolumn{1}{c}{ DISEASE DATA } \\
\hline CODE & \multicolumn{1}{c}{ DISEASE } \\
\hline P01 & Ear lice \\
P02 & Scabies \\
P03 & Diarrhea due to food changes \\
P04 & Clamedia \\
P05 & Ring Worm \\
P06 & Flu \\
P07 & Panleukopenia \\
P08 & Worms \\
P09 & Kidney failure \\
P10 & Calici Virus \\
P11 & Flu Rhino \\
P12 & Have a cold \\
P13 & Lice on the body \\
P14 & Pyometra/Inflammation of the uterus \\
P15 & Difficult BAB \\
P16 & Dehydration \\
P17 & Food poisoning \\
P18 & Apoplexy/Epilepsy \\
\hline
\end{tabular}

b. Symptom Data

TABLE 2.

\begin{tabular}{|c|c|}
\hline CODE & SYMPTOM \\
\hline G01 & Pale Tonque \\
\hline G02 & Pale Gums \\
\hline G03 & Pale Eyes \\
\hline G04 & Cold Ears \\
\hline G05 & Earwax like coffee grounds \\
\hline G06 & Itchy skin \\
\hline
\end{tabular}




\begin{tabular}{cl}
\hline CODE & SYMPTOM \\
\hline G07 & When the ear drops are put on, the ears will foam \\
G08 & Reddish skin \\
G09 & Hair loss \\
G10 & Dry skin \\
G11 & Swelling of itchy skin \\
G12 & Excessive self-licking \\
G13 & Thin body \\
G14 & Wet ass \\
G15 & The eyes are getting bigger \\
G16 & Eyes turn white, one or both \\
G17 & Fever \\
G18 & Infected skin looks circular \& scaly with a reddish side \\
G19 & Watery eyes and nose \\
G20 & Excessive saliva \\
G21 & Sneeze \\
G22 & Cough \\
G23 & Gingivitis \\
G24 & Sore throat \\
G25 & Throw up \\
G26 & Diarrhea \\
G27 & Enlarged belly \\
\hline
\end{tabular}

c. Cause and solution data

TABLE 3.

DiseAse CAUSES AND SOLUTIONS

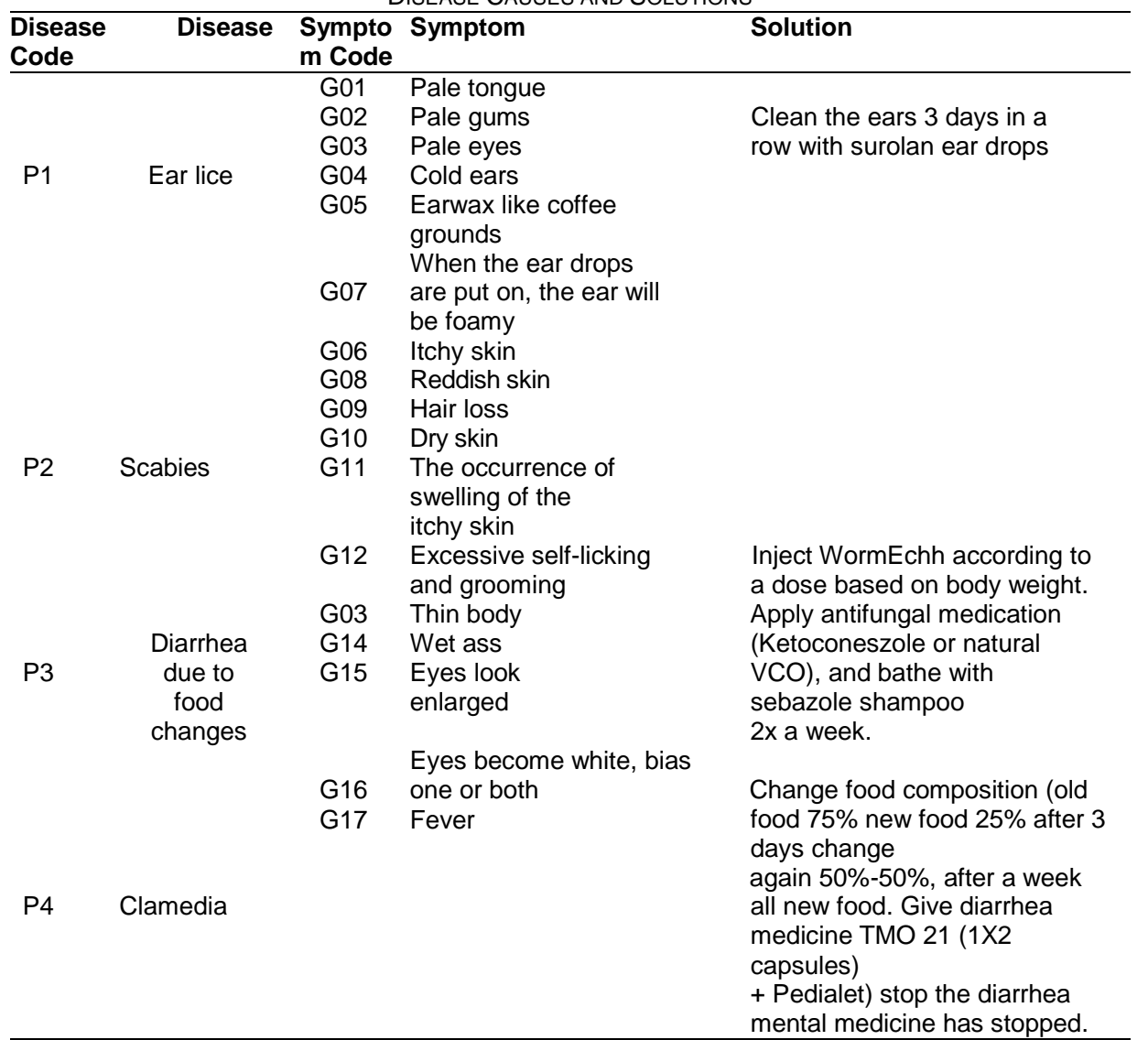

d. Symptom rule 
After knowing the disease data and symptoms, the researcher can make a truth table. The table of rules can be seen in the following table.

TABLE 4.

CASE STUDY

\begin{tabular}{ll}
\hline Num & \multicolumn{1}{c}{ Disease Symptom Rules } \\
\hline 1 & $\begin{array}{l}\text { IF (pale tongue) AND (pale gums) AND (pale eyes) AND (cold ears) AND (ear } \\
\text { wax like coffee grounds) AND (When you put ear drops, your ears will foam) } \\
\text { THEN Ear lice. }\end{array}$ \\
2 & $\begin{array}{l}\text { IF Itchy skin AND Reddish skin AND Hair loss AND Dry skin AND Swelling of } \\
\text { itchy skin Excessive licking and self-care THEN Scabies }\end{array}$ \\
3 & $\begin{array}{l}\text { IF Thin Body AND Wet Ass AND Enlarged Eyes } \\
\text { THEN Diarrhea Due to Changes in Food }\end{array}$ \\
4 & $\begin{array}{l}\text { IF Eyes turn white, it can be one or both AND Fever } \\
\text { THEN Clamedia }\end{array}$ \\
& $\begin{array}{l}\text { IF Itching \& rash on the skin AND Infected skin looks circular \& scaly with reddish } \\
\text { sides AND Dry skin THEN Ring Worm }\end{array}$ \\
& $\begin{array}{l}\text { IF Running eyes \& nose AND excessive saliva AND sneezing AND } \\
\text { Thrush AND Gingivitis THEN Flu }\end{array}$ \\
& IF Watery eyes AND Dirty ears AND Diarrhea AND Enlarged stomach \\
& THEN Worms \\
IF Increased frequency of urination AND difficulty in CHAPTER AND \\
Shortness of breath AND Decreased appetite AND dehydration AND \\
diarrhea and vomiting THEN Kidney failure
\end{tabular}

The following are examples of old cases and new cases to test the stages case based reasoning.

Table 5.

\begin{tabular}{cl}
\multicolumn{2}{l}{ Comparison of old cases with new cases } \\
\hline Num & \multicolumn{1}{c}{ New Case } \\
\hline 1 & Itchy skin \\
2 & Dry skin \\
3 & Pale Eyes \\
4 & Reddish Skin \\
5 & Excessive self-licking \\
\hline
\end{tabular}

In the diagnosis of new cases above, the results are based on old cases of 18 types of cat diseases. The results of the calculations can be seen in the following table:

Table 6.

New Case Count

\begin{tabular}{cccccc}
\hline Case & $\begin{array}{l}\text { Symptom } \\
\text { Suitable }\end{array}$ & $\begin{array}{c}\text { Symptom } \\
\text { Case }\end{array}$ & $\begin{array}{c}\text { Symptom } \\
\text { Chosen }\end{array}$ & Divider & Results \\
\hline 01 & 1 & 6 & 5 & 6 & $1 / 6=0.1667$ \\
02 & 4 & 6 & 5 & 6 & $4 / 6=0.6667$ \\
03 & & 3 & 5 & 5 & $/ 5=0$ \\
04 & & 2 & 5 & 5 & $/ 5=0$ \\
05 & 2 & 3 & 5 & 5 & $2 / 5=0.4$ \\
06 & & 4 & 5 & 5 & $/ 5=0$ \\
07 & & 4 & 5 & 5 & $/ 5=0$ \\
08 & & 3 & 5 & 5 & $/ 5=0$ \\
09 & & 5 & 5 & 5 & $/ 5=0$ \\
10 & & 4 & 5 & 5 & $/ 5=0$ \\
11 & & 2 & 5 & 5 & $/ 5=0$ \\
12 & & 4 & 5 & 5 & $/ 5=0$ \\
13 & 1 & 2 & 5 & 5 & $1 / 5=0.2$ \\
14 & & 1 & 5 & 5 & $/ 5=0$ \\
15 & & 1 & 5 & 5 & $/ 5=0$ \\
16 & & 1 & 5 & 5 & $/ 5=0$ \\
17 & & 5 & 5 & 5 & $/ 5=0$ \\
18 & & 4 & 5 & 5 & $/ 5=0$ \\
\hline
\end{tabular}

In the new case above, there were 4 old cases that matched the symptoms in the new case, namely, cases $01,02,05,13$. 
Case $01=$ Matched Symptoms $/$ Max Value (Case Symptoms, Selected Symptoms) ${ }^{*} 100$

$=(1 /(\max 5,6) * 100$

$=0.1667{ }^{*} 100$

$=16.67 \%$

Case $02=$ Matched Symptoms $/$ Max Value (Case Symptoms, Selected Symptoms) ${ }^{*} 100$

$=(4 /(\max 5,6) * 100$

$=0.6667 * 100$

$=66.67 \%$

Case $05=$ Matched Symptoms $/$ Max Value (Case Symptoms, Selected Symptoms) ${ }^{*} 100$

$=\left(2 /(\max 3.5){ }^{*} 100\right.$

$=0.4 * 100$

$=40 \%$

From the results of the above calculations obtained analysis and percentage as follows.

Table 6.

Analysis and Percentage

\begin{tabular}{lrlc}
\hline No & Kasus & Penyakit & Persentase \\
\hline 1 & 02 & Scabies & $66.67 \%$ \\
2 & 05 & Ring Worm & $40 \%$ \\
3 & 13 & Lice on the body & $20 \%$ \\
4 & 01 & Ear lice & $16.67 \%$ \\
5 & 17 & Food poisoning & $0 \%$ \\
6 & 16 & Dehydration & $0 \%$ \\
7 & 15 & Difficult BAB & $0 \%$ \\
9 & 12 & Have a cold & $0 \%$ \\
10 & 10 & Calici Virus & $0 \%$ \\
11 & 11 & Flu rhino & $0 \%$ \\
12 & 09 & Kidney failure & $0 \%$ \\
13 & 08 & Worms & $0 \%$ \\
14 & 07 & Panleukopenia & $0 \%$ \\
15 & 06 & Flu & $0 \%$ \\
16 & 04 & Clamedia & $0 \%$ \\
\hline
\end{tabular}

\section{CONCLUSION}

The Bengal Cat Disease Expert System application has been successfully created. This application has successfully implemented the Case base reasoning method which is used in the disease diagnosis process to provide a level of confidence in the symptoms of a disease. Features of the Paddy Disease Doctor application include: disease data, symptom data, knowledge data. Consultation. And this expert system application has been able to diagnose diseases in cats based on the symptoms entered by the user, using the Case Base Reasoning method. This application has the following facilities: data entry, addition, editing, and deletion of existing data on the system. The program will displays all values of the symptoms entered by the user, but only the highest value will be displayed.

\section{References}

Anggilina, A., \& Eviyanti, A. (2021). Web-Based Expert System for Diagnosing Gastric Disease Using Bayes Theorem Method. Procedia of Engineering and Life Science, 1(2).

Broussard, M. (2015). Artificial intelligence for investigative reporting: Using an expert system to enhance journalists' ability to discover original public affairs stories. Digital Journalism, 3(6), 814-831.

De Paz, J. F., Rodríguez, S., Bajo, J., \& Corchado, J. M. (2009). Case-based reasoning as a decision support system for cancer diagnosis: A case study. International Journal of Hybrid Intelligent Systems, 6(2), 97110.

Fernandez-Riverola, F., Díaz, F., \& Corchado, J. M. (2006). Reducing the memory size of a fuzzy case-based reasoning system applying rough set techniques. IEEE Transactions on Systems, Man, and Cybernetics, Part C (Applications and Reviews), 37(1), 138-146.

Fidyaningsih, S., Agus, F., \& Maharani, S. (2016). Sistem Pakar Diagnosa Penyakit Kucing Menggunakan Metode Case-Based Reasoning. Prosiding Seminar IImu Komputer Dan Teknologi Informasi, Program Studi IImu Komputer, Fakultas IImu Komputer Dan Teknologi Informasi Universitas Mulawarman, 
Kampus Gunung Kelua Barong Tongkok Samarinda, Kalimantan Timur, 1(1).

Hadj-Mabrouk, H. (2020). Application of Case-Based Reasoning to the safety assessment of critical software used in rail transport. Safety Science, 131, 104928.

Jiang, X., Wang, S., Wang, J., Lyu, S., \& Skitmore, M. (2020). A decision method for construction safety risk management based on ontology and improved CBR: Example of a subway project. International Journal of Environmental Research and Public Health, 17(11), 3928.

Kamal, M. M. (2006). An intelligent classification system for land use and land cover mapping using spaceborne remote sensing and GIS. Middlesex University.

Kurniati, N., Yanitasari, Y., Lantana, D. A., Karima, I. S., \& Susanto, E. R. (2017). Sistem Pakar Untuk Mendiagnosa Penyakit Kulit Pada Kucing Menggunakan Certainty Factor. ILKOM Jurnal IImiah, 9(1), 34-41.

Liao, S.-H. (2005). Expert system methodologies and applications-a decade review from 1995 to 2004. Expert Systems with Applications, 28(1), 93-103.

Masethe, M. A., Ojo, S. O., Odunaike, S. A., \& Masethe, H. D. (2021). Framework of Recommendation Systems for Educational Data Mining (EDM) Methods: CBR-RS with KNN Implementation. In Transactions on Engineering Technologies (pp. 87-98). Springer.

Muktar, M., Rahmayu, M., \& Sudrajat, B. (2020). Sistem Pakar Diagnosa Penyakit Tht Berbasis Web Dengan Menggunakan Metode Certainty Factor. Jurnal Inovasi Informatika, 5(1), 45-54.

Purnomo, A. A. N., Andryana, S., \& Iskandar, A. (2020). Application of Expert System for Diagnosing Gastric Disease Android Based with Certainty Factor Method. Jurnal Teknik Informatika CIT Medicom, 12(1), 715.

Salat, J., Rizal, M., Harahap, W., \& Setiawati, C. L. (2021). Expert System of Blood Fever Disease Using Case Based Reasoning (CBR) Method. INTERNATIONAL JOURNAL OF EDUCATION, SOCIAL SCIENCES AND LINGUISTICS, 1(1), 50-68.

Setiawan, I., Fauziah, F., \& Andrianingsih, A. (2020). Expert System for Diagnosing Diseases in Cats that Can Contagious to Humans Using the Certainty Factor Method: Expert System for Diagnosing Diseases in Cats that Can Contagious to Humans Using the Certainty Factor Method. Jurnal Mantik, 3(4), 474-483.

Sutrisna, A. A., Sidik, S., Rahajeng, I. R., \& Ryansyah, M. (2021). Expert System Diagnosis of Skin Disease in Cat with Forward Chaining Method. Jurnal Mantik, 5(3), 1766-1774. 